\title{
50 Years SYNTHESIS - Golden Anniversary Issue
}

\section{Dear SYNTHESIS readers,}

Happy Birthday SYNTHESIS! Our journal is now 50 years old.

In the last 50 years, SYNTHESIS has published original synthetic work from organic chemists all over the world.

Since 1969, when our journal first appeared, the field of synthetic organic chemistry has changed considerably, and a leading organic chemist of 1969 would certainly have difficulty in following the chemistry described in synthetic schemes found in publications from 2019. There are, however, some things that remain invariant over time; for example, Dieter Seebach published his seminal review on umpolung in 1969 and he is also a contributor to this Golden Issue of 2019.

For this issue, we have invited some of the most prestigious organic chemists to contribute a publication of their recent work. More than 60 leading organic chemists from all over the world have accepted and their work will appear in two Golden Issues (Parts I and II). We are very proud to publish this important body of research and all contributions of the Golden Issues will be published Open Access in electronic form to allow maximum access to the scientific community. This issue expresses our trust in the importance of synthetic organic chemistry in the future of the larger field of organic chemistry.

Two new editors have joined our team: Prof. Hideki Yorimitsu, Kyoto University, who replaces Tohru Fukuyama, and Prof. Franziska Schoenebeck from RWTH Aachen University, who will take over the responsibilities from Erick Carreira regarding the organization of Special Topics and occasional Special Issues.

Both Erick and Tohru joined the SYNTHESIS board in 1998. We would like to take this opportunity to thank them very much for their great commitment over the last 20 years.

Finally, we would like to thank all the authors from SYNTHESIS for the trust they place in our editorial team for handling their manuscripts and publishing their work.

We hope that you will all enjoy reading this special birthday issue, and we wish you a Happy and Successful New Year!

Paul Knochel, Editor-in-Chief

LMU Munich

December 2018

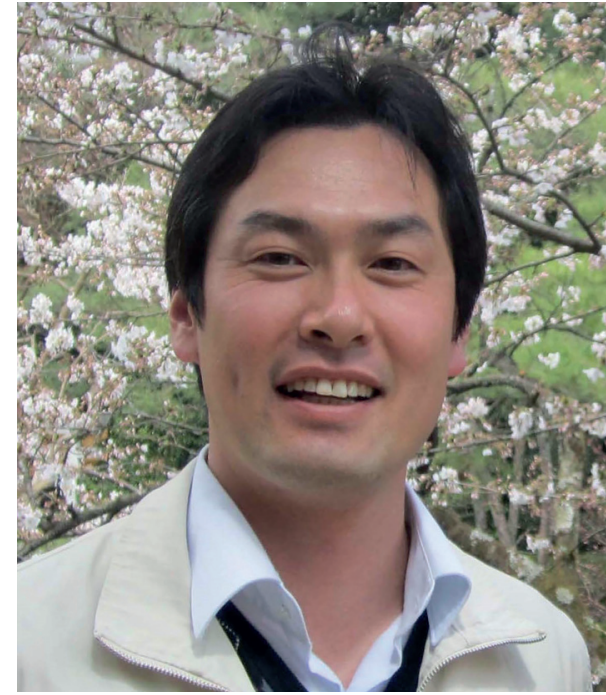

Prof. Hideki Yorimitsu

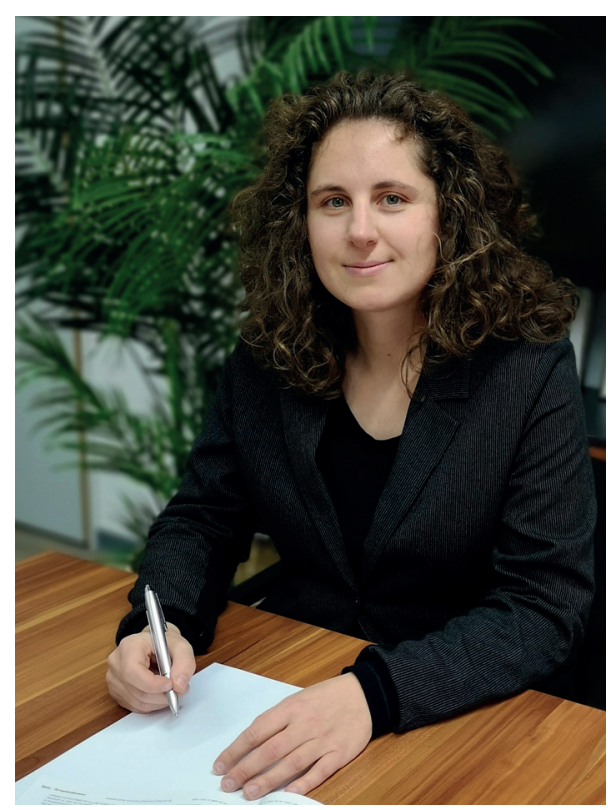

Prof. Franziska Schoenebeck 


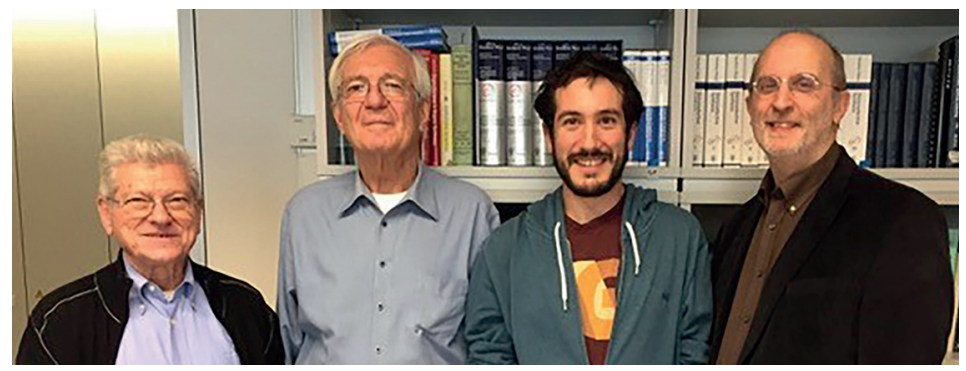

D. Seebach and co-authors

Dem Journat Synthesis gratuliere ich zum 50. Geburtstag. Die jetzigen und früheren Herausgeber und die Thieme. Mannschaft haben seit der Gründung im Jahre 1969 zahtreiche wegweisenden Arbeiten publiziert, und mit SYNLETT, Synopen, SYNFACTS und SYNFORM gewissermaßen Nachkommen hervorgebracht, alle mit Schwerpunkt auf unsere getiebte Kunst und Wissenschaft der Organischen Synthese.

Es frent mich, dass ich sowoht im allerersten Heft (Synthesis 1969, S. 17, "Nucleophite Acylierung") als auch im jetzigen Jubiäumsheft (Synthesis 2019, "Synthesis of Cyanophycin Segments for Investigations of Cell Penetration") zusammen mit meinen Helfern eine Veröffentlichung beitragen durfte, wobei die beiden Titel Schwerpunktsverschiebungen in der Organischen Synthese und die de-facto Ablösung von Deutsch durch Englisch als Sprache der Wissenschaft widerspiegeln.

Für die nächsten Dekaden wünsche ich der Synthesis weiterhin viel Erfolg, das heißt einen hohen Impaktfaktor, und den Autoren und Herausgebern Freude an der Verbreitung neuer Synthesemethoden und künftiger Syntheseziele.

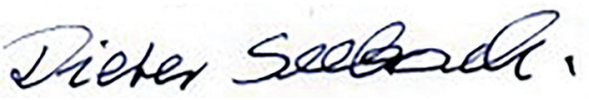

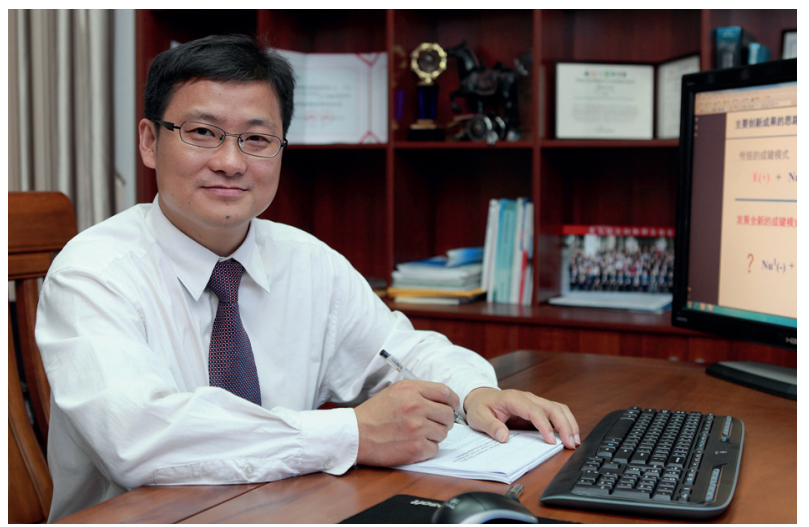

A. Lei
Ancient Chinese philosopher Confucius said: "At fifty, 1 knew the will of Heaven". The past half century has witnessed that synthesis is acting a greater role for the betterment of mankind. On the occasion of this wonderful moment, 1 would like to say happy birthday and synthesize our brilliant future.

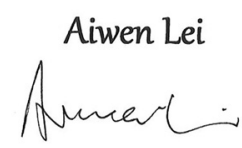

Wuhan University 


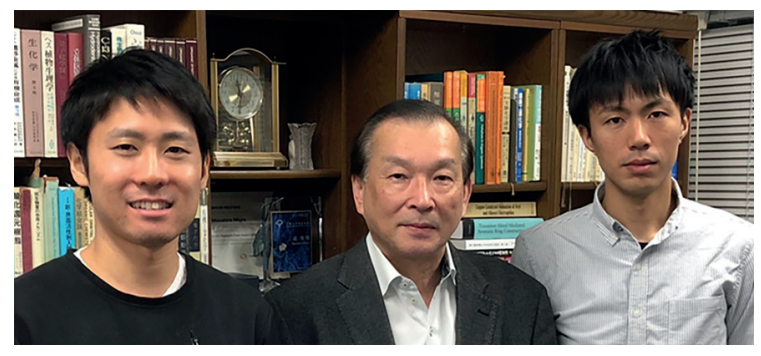

M. Miura group
Congratulations on

\section{Syutheir 50 th Annioursary}

祝50周年

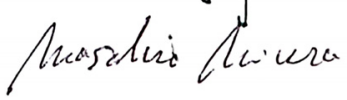

Yoyi Nichio

Feppei Noguhti

$$
\begin{aligned}
& 50 \text { years of exallent fervic } \\
& \text { to the erganic Clemist ty } \\
& \text { comsunity. } \\
& \begin{array}{l}
\text { Lup goung strong! } \\
\text { Of. Wollow oum }
\end{array}
\end{aligned}
$$

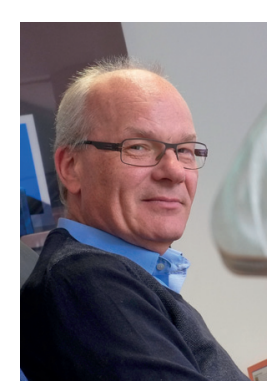

H. Waldmann

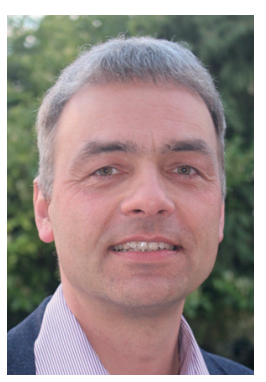

T. Wirth

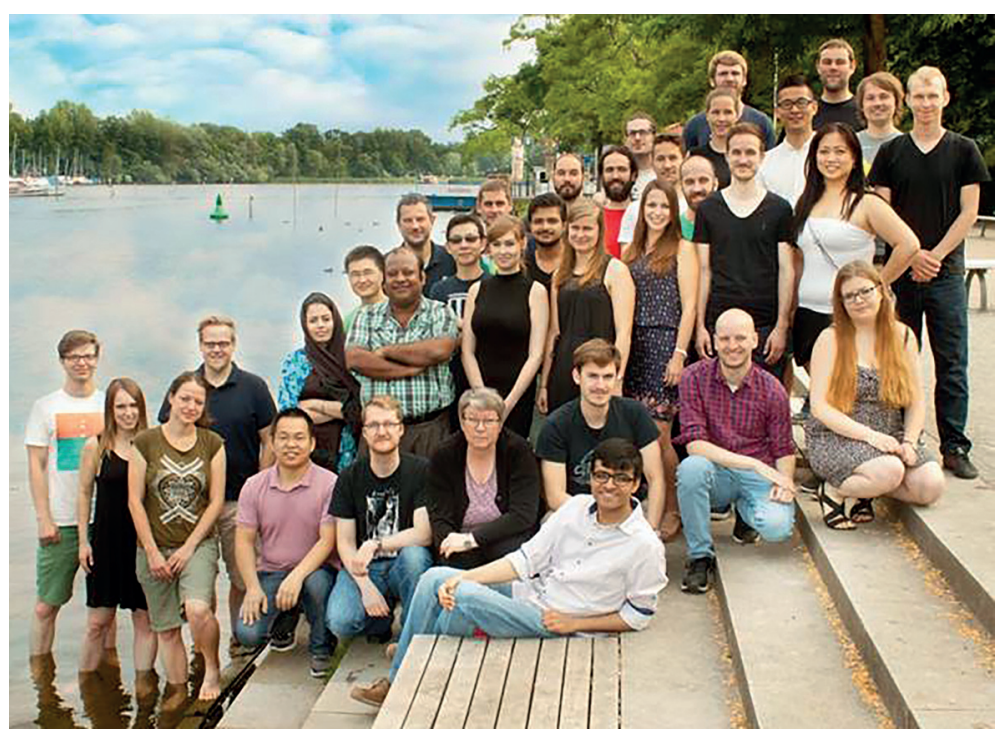

M. Oestreich group
Dear SYNTTESIS,

Shiff and Authers for 50

yeas of succers.

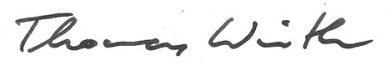

Congratulations to all Editors, decunter 2, 20,18

3 have been a follower of

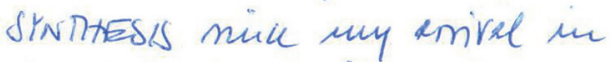
the laboratory of bicter Hoppe. instener torogk serred as an editor at that Hine and semird the high standards of the journal. Hunot to years later, Jin rateris is Nill gring soong and is Clebrating its Soth muivesary. HAPPY BRTHATY and Continued success in the ever-champg putisining binuen. hatin linvich Th Berlin 

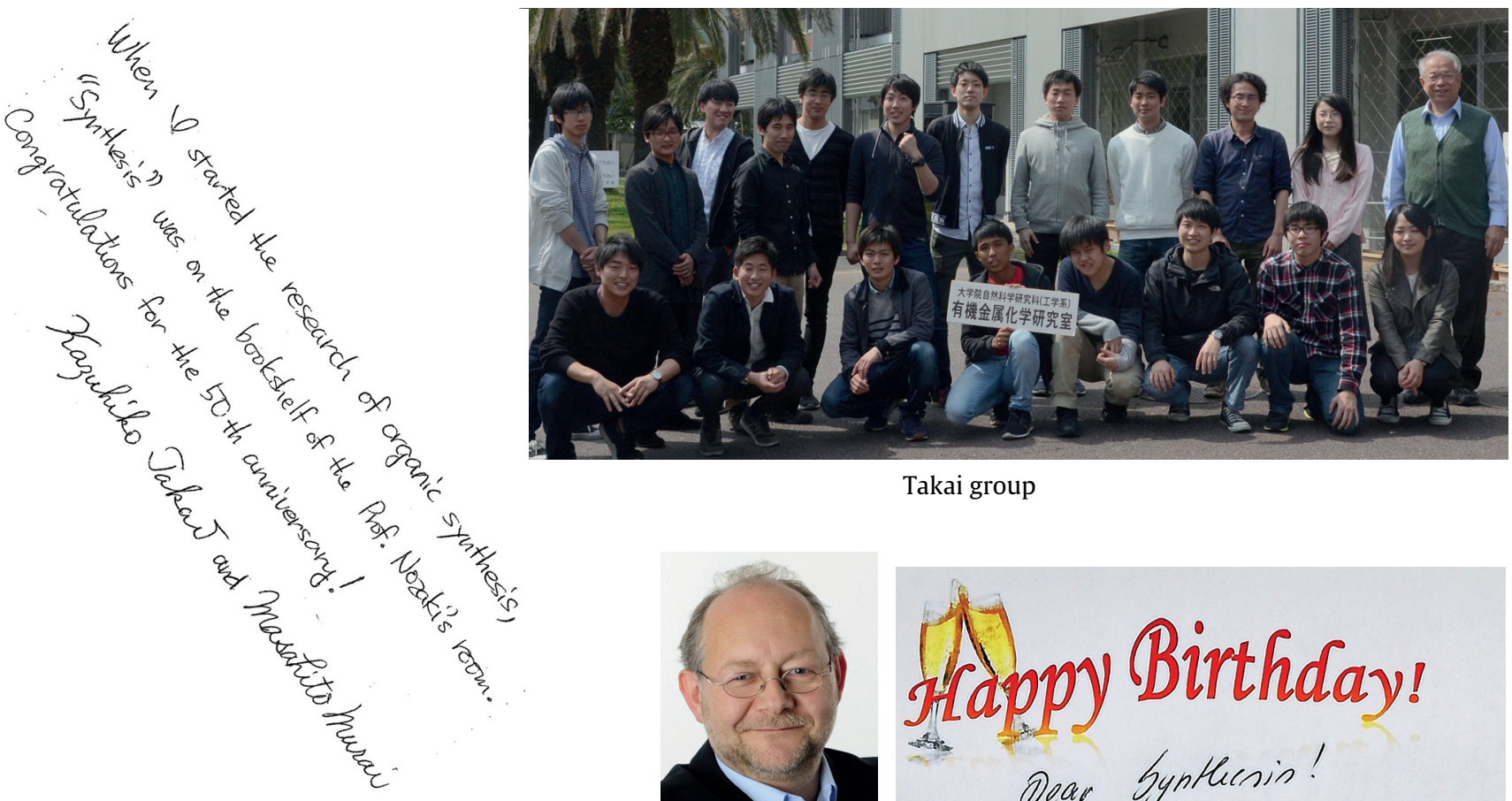

Takai group

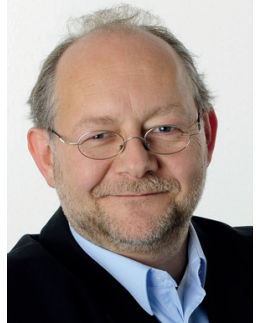

U. Kazmeier

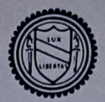

THE UNIVERSITY OF NORTH CAROLINA AT
CHAPEL HIL

Department of Chemistry

Please accept my best wishes and congratulations on the occasion of the GOLDEW SYNTHESIS Anniversary Special desue!

Verytruly yours, Ceffrey jelusion

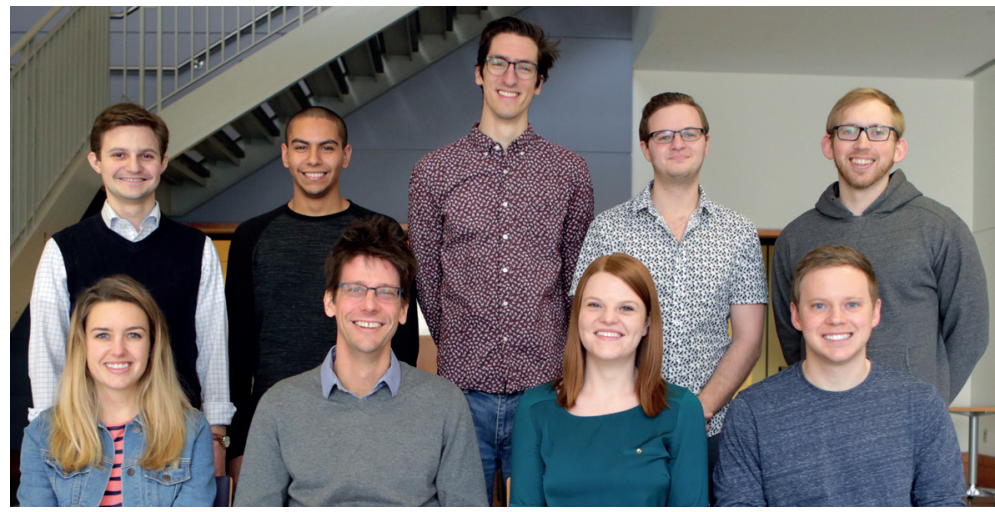

Johnson group

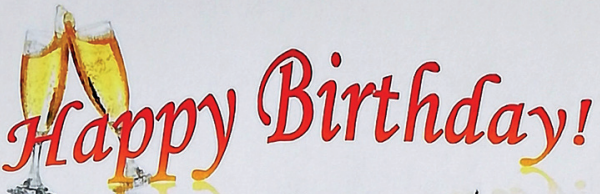

Oear Gyntlensin!

Since mere Hean 28 years, prom the begruming of uny scieutific career you lean b-en a carstaut comparion or all the years.

Mevefore. Mush you all the lest, oet least for decoller 50 years. Henpy Porthedas

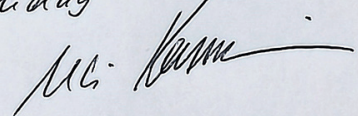




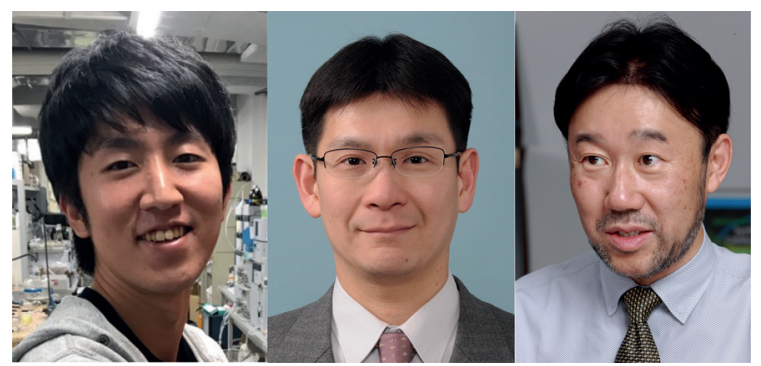

Kobayashi group

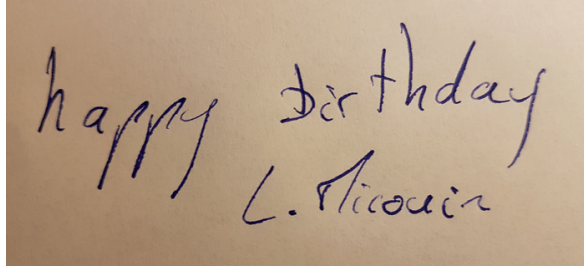

Looking forwad to the next 50 years of Syathesis, a great journal that has kept a high profile. Propry borthday! Gwillerm Evavo

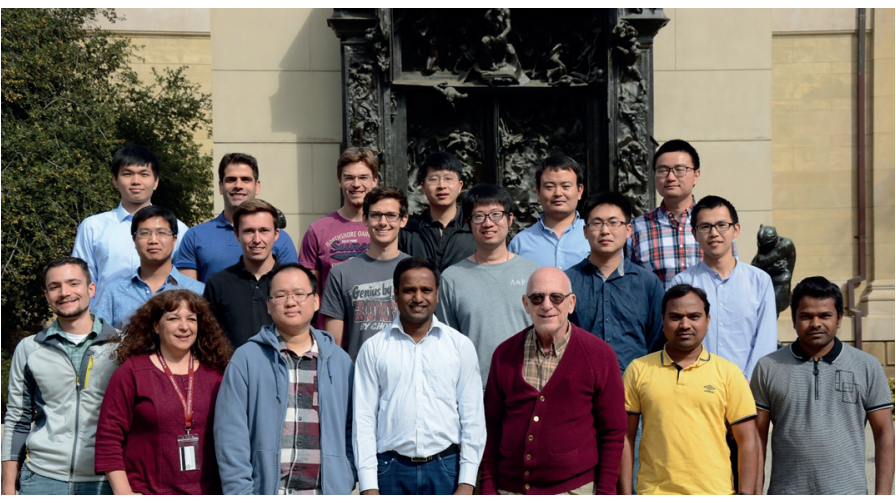

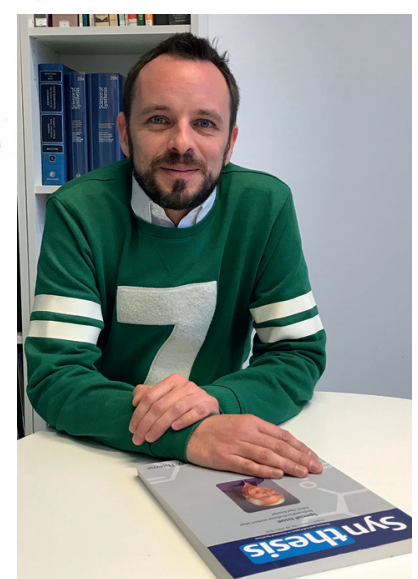

G. Evano such speial birthdays in the years to come.

$$
\text { Bary on Jeat. }
$$

Happy Birtholay

All the best la the furuse of sypthesis
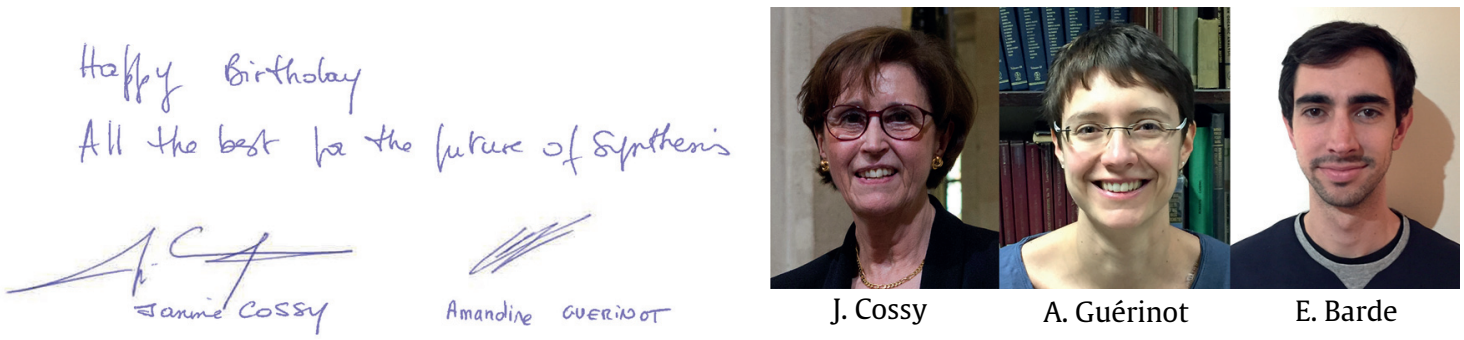

E. Barde

L. Micouin

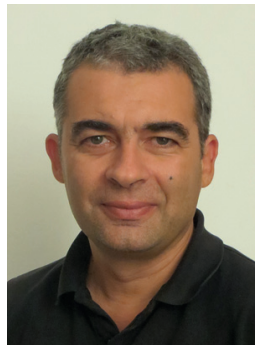




\section{Synthesis}

Editorial

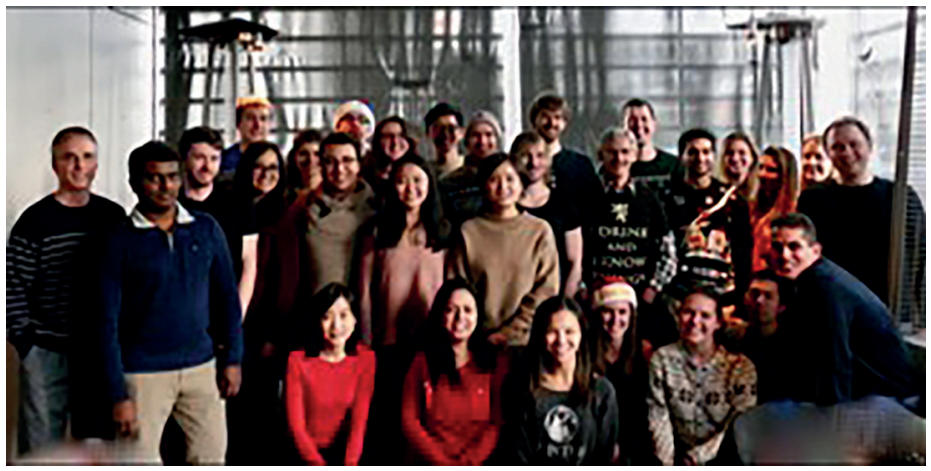

Wipf group

$$
\begin{aligned}
& \text { Happy Birthday, Syn thesis! } \\
& \text { great to be port of you } \\
& \text { golden celobration, Peter }
\end{aligned}
$$

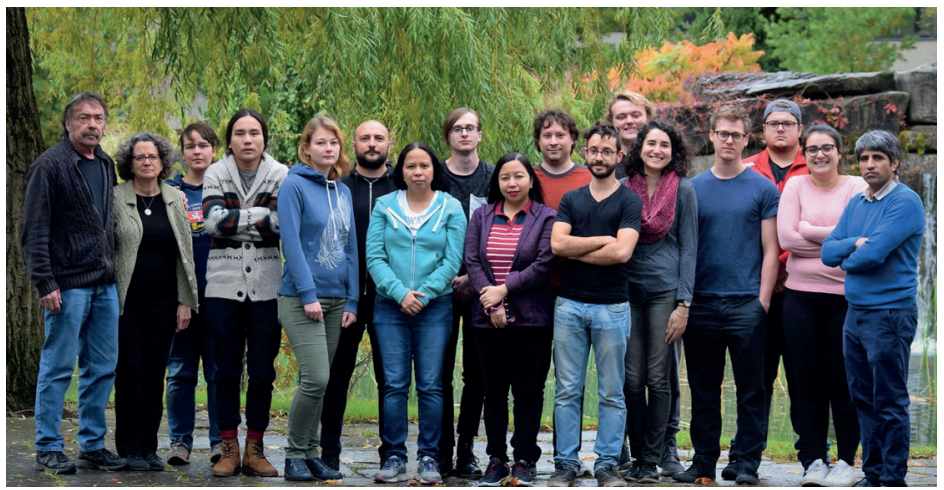

Hudlicky group

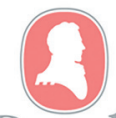

Tomas Hudlicky

B10CK

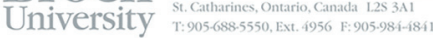

To: SYNTHESIS

Happy $50^{\text {th }}$ Birthday and many more.

Toma videllichs

Tomas Hudlicky

Canada Research Chair (Tier I) in Organic Synthesis and Biocatalysis
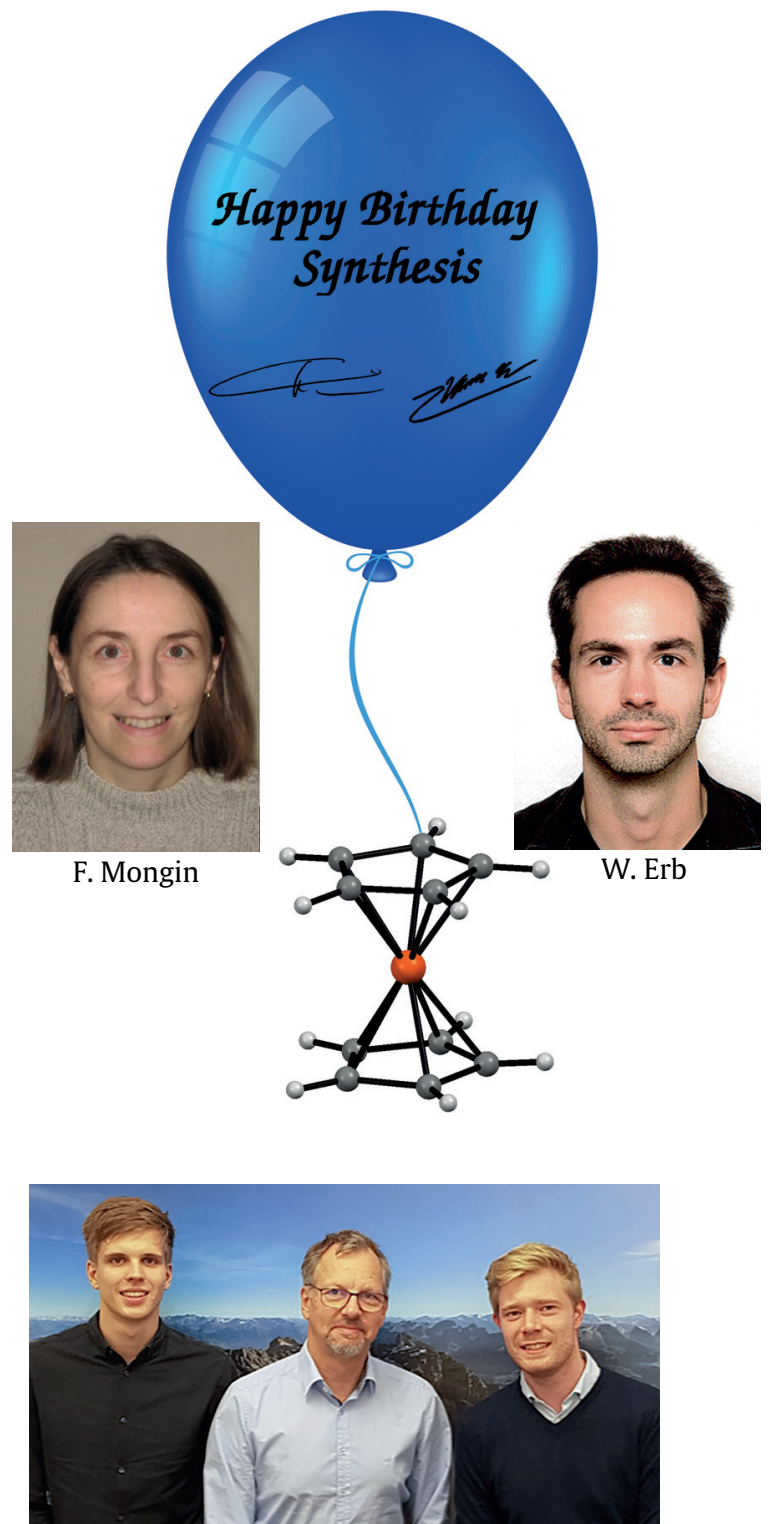

M. Kalesse and co-workers

Dear SYNTESIS, all the best to your

50 th anniversary. Celebroting the soth year denoles that 7 times 7 years hore passed. This was already in ancient Israel a year of joy and festivity. Now, we look back with gratituch at 50 years of seminal papers and inmovative chemistry. With this I can't o wait your future contributions to chemistry.

Aer the best 


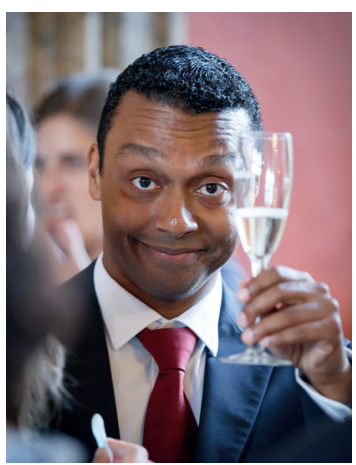

$$
50 \text { yeaus already! Happy Anuversany to a journal }
$$

whith, after 5 decades, is fresher and younger than

$$
\text { pechaps ever before! Cheers! }
$$

$$
\text { Nungaubri }
$$

N. Maulide

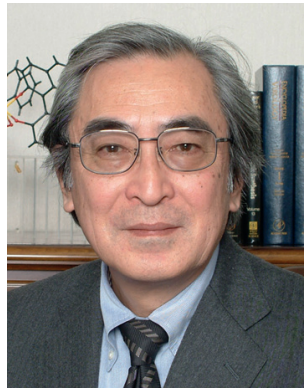

M. Shibasaki

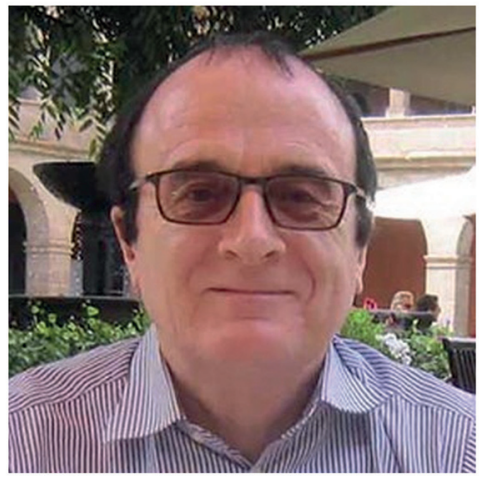

It is my grect preccure to witness the half century anniuersary of SYNTHFSis; will continue to spur chenistery conumunity.
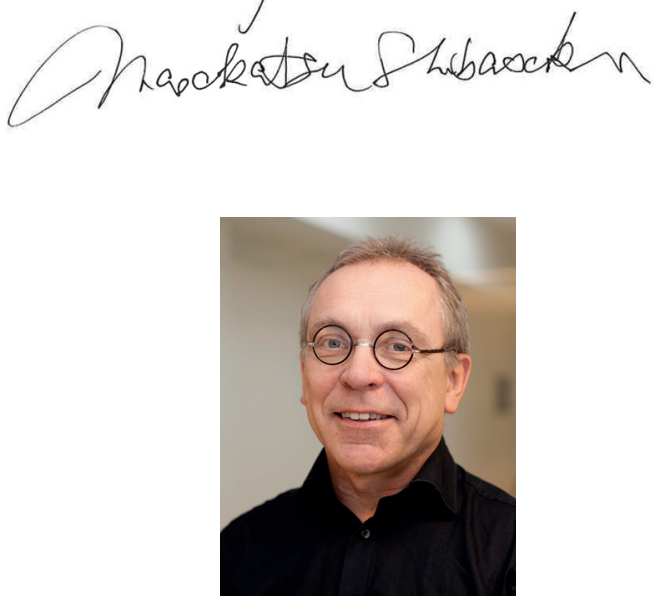

A. Koskinen

Of course I wish to express my warmest birthday congratulations to SYNTHESIS for reaching the mature age of 50 !

Ari Koskinen

Happy 50th Birthday Synthesis; we all look forward to the next Golden Issue in 2069

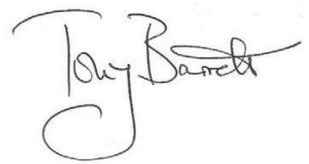

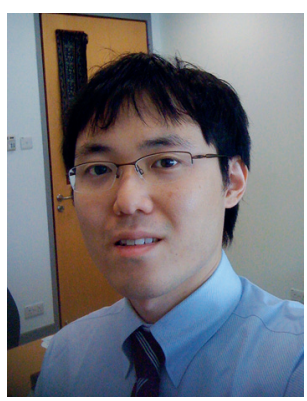

Happy 50 th Birthday to SYNTHESIS!

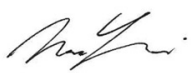

N. Yoshikai 